\title{
In vitro/in vivo performance of different complexes of itraconazole used in the treatment of vaginal candidiasis
}

\author{
Mohammad Aamir Mirza1, Mohammad Akhlaquer Rahman², Sushama Talegaonkar', \\ Zeenat Iqbal,"*
}

\author{
${ }^{1}$ Department of Pharmaceutics, Faculty of Pharmacy, Jamia Hamdard, New Delhi, India, ${ }^{2}$ Faculty of Pharmacy, \\ Integral University, Lucknow, India
}

\begin{abstract}
A large majority of new chemical entities and many existing drug molecules exhibit poor aqueous solubility, which may limit their potential use in developing drug formulations, with optimum bioavailability. One of the approaches to improve the solubility of a poorly water soluble drug and eventually its bioavailability is complexation with agents like humic acid (HA), fulvic acid (FA), $\beta$-cyclodextrin ( $\beta$-CD), 2-hydroxypropyl- $\beta$-cyclodextrin (HP- $\beta$-CD) and caffeine (Caff). The current work emphasized at employing these agents to prepare different complexes and their in vitro/in vivo assessment. All the complexes evaluated for their complexation efficiency and authenticated by molecular modeling; conformational analysis, differential scanning calorimetry (DSC), X-ray diffraction (XRD), nuclear magnetic resonance (NMR) and mass spectroscopy. Furthermore, the complexes were assessed in an in vivo, rat vaginal model for their efficacy in treatment of vaginal candidiasis. Amongst the five tested complexes, fulvic acid-itraconazole complex yielded better solubility as well as in vivo efficacy and therefore may further be explored for developing a commercial formulation for treating vaginal candidiasis.
\end{abstract}

Uniterms: Itraconazole/complexes/evaluation. Itraconazole/complexes/in vitro/in vivo performance. Vaginal candidiasis/treatment. Drugs/solubility. Drugs/formulation.

A maioria das novas entidades químicas e muitas moléculas de fármacos existentes apresenta fraca solubilidade em água, o que pode limitar seu uso potencial no desenvolvimento de formulações com biodisponibilidade ideal. Uma das abordagens para melhorar a solubilidade de um fármaco pouco solúvel em água e, eventualmente, a sua biodisponibilidade é a complexação com agentes como o ácido húmico (HA), ácido fúlvico (FA), $\beta$-ciclodextrina ( $\beta-C D)$, 2-hidroxipropil- $\beta$-ciclodextrina (HP- $\beta$-CD) e cafeína (Caff). O presente trabalho baseia-se no uso desses agentes para preparar diferentes complexos e suas avaliações in vitro/in vivo. Todos os complexos foram avaliados quanto à eficiência de complexação por modelação molecular, análise conformacional, calorimetria de varredura diferencial (DSC), difração de raios-X (XRD), ressonância magnética nuclear (RMN) e espectroscopia de massas. Além disso, os complexos foram avaliados in vivo, em ratas, no tocante à sua eficácia no tratamento de candidíase vaginal. Entre os cinco complexos testados, o complexo de ácido fúlvico-itraconazol foi o que apresentou melhor solubilidade, bem como melhor eficácia in vivo e, portanto, pode ser explorado para o desenvolvimento de uma formulação comercial para o tratamento de candidíase vaginal.

Unitermos: Itraconazol/complexos/avaliação. Itraconazol/complexos/desempenho in vitro/in vivo. Candidíase vaginal/tratamento. Fármacos/solubilidade. Fármacos/formulação.

* Correspondence: Zeenat Iqbal. Department of Pharmaceutics, Faculty of Pharmacy, Jamia Hamdard, 110062 - New Delhi, India. E-mail: ziqbaljh@yahoo.co.in 


\section{INTRODUCTION}

It is estimated that nearly $40 \%$ of the newly developed drugs have an aqueous solubility of less than $100 \mu \mathrm{g} / \mathrm{mL}(100 \mathrm{ppm})$ and some even lower than $1 \mu \mathrm{g} / \mathrm{mL}$ (Prentis et al., 2003). This poor solubility becomes an impediment for the in vivo success of their formulations as it limits the bioavailability of such drugs. Antifungals along with many other categories of newer drugs suffer from this problem. The approval of the triazoles in the early 1990s was a major progress in the ability to safely and effectively treat local and systemic fungal infections (Maertens, 2004). Itraconazole (Itz), a member of this class has attracted considerable attention for the treatment of wide range of fungal infections with considerably lower toxicity and a better therapeutic index when compared to Amphotericin B (Como, Dismukes, 1994). However limited aqueous solubility and dissolution rate of Itz has been responsible for its poor absorption and consequently lower bioavailability (Bailey et al., 1990; Grant, Clissold, 1989). It is a weak basic drug, possessing extremely low water solubility $(S \sim 1 \mathrm{ng} / \mathrm{ml}$ at neutral $\mathrm{pH})$. The calculated $\log P$ is 6.2 (Peeters et al., 2002) which indicate its high lipophilicity. Although Itz has elicited hydrophobic properties it is neither hydrophilic nor lipophilic at room temperature. Thus, it has always been a challenge to deliver this drug in a suitable dosage form. A technique that helped in bringing this molecule into the market (Sporanox ${ }^{\circledR}$ by Janssen Pharmaceuticals) was inclusion complexation with 2-hydroxypropyl- $\beta$-cyclodextrin. Since the development of inclusion complexes of Itz has been well proven, this study explored the potential of various complexing agents from different sources to address the solubility problem of the molecule. Complexing agents (Figure 1) selected for the study were humic acid (HA), fulvic acid (FA), $\beta$-cyclodextrin ( $\beta$-CD), 2-hydroxypropyl- $\beta$-cyclodextrin

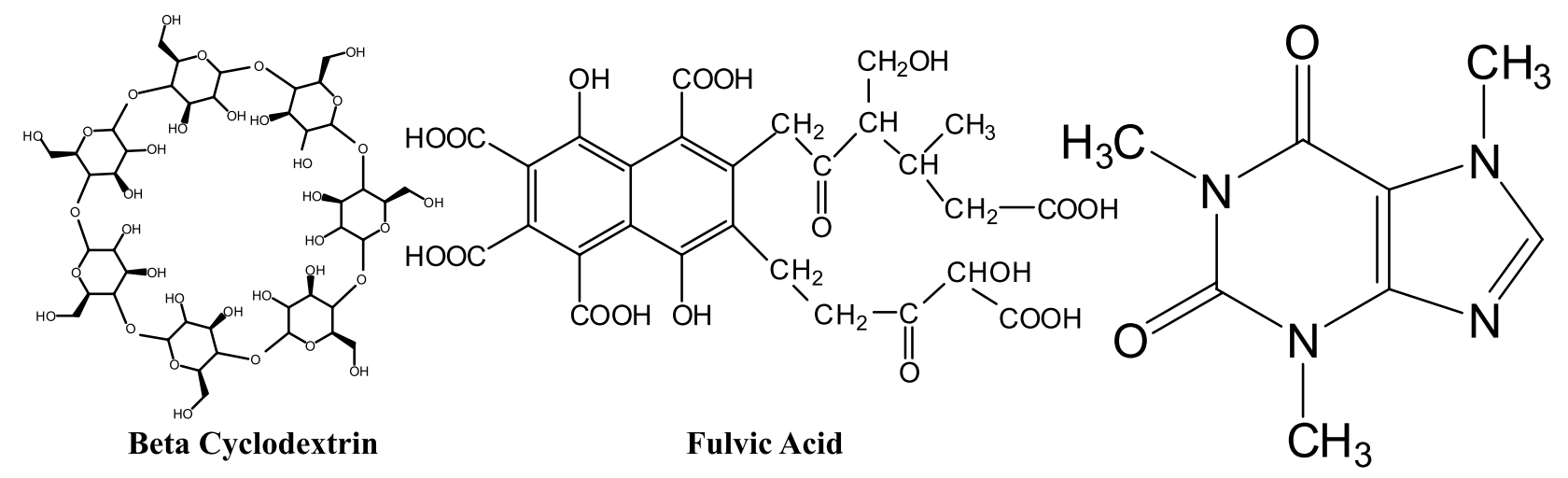

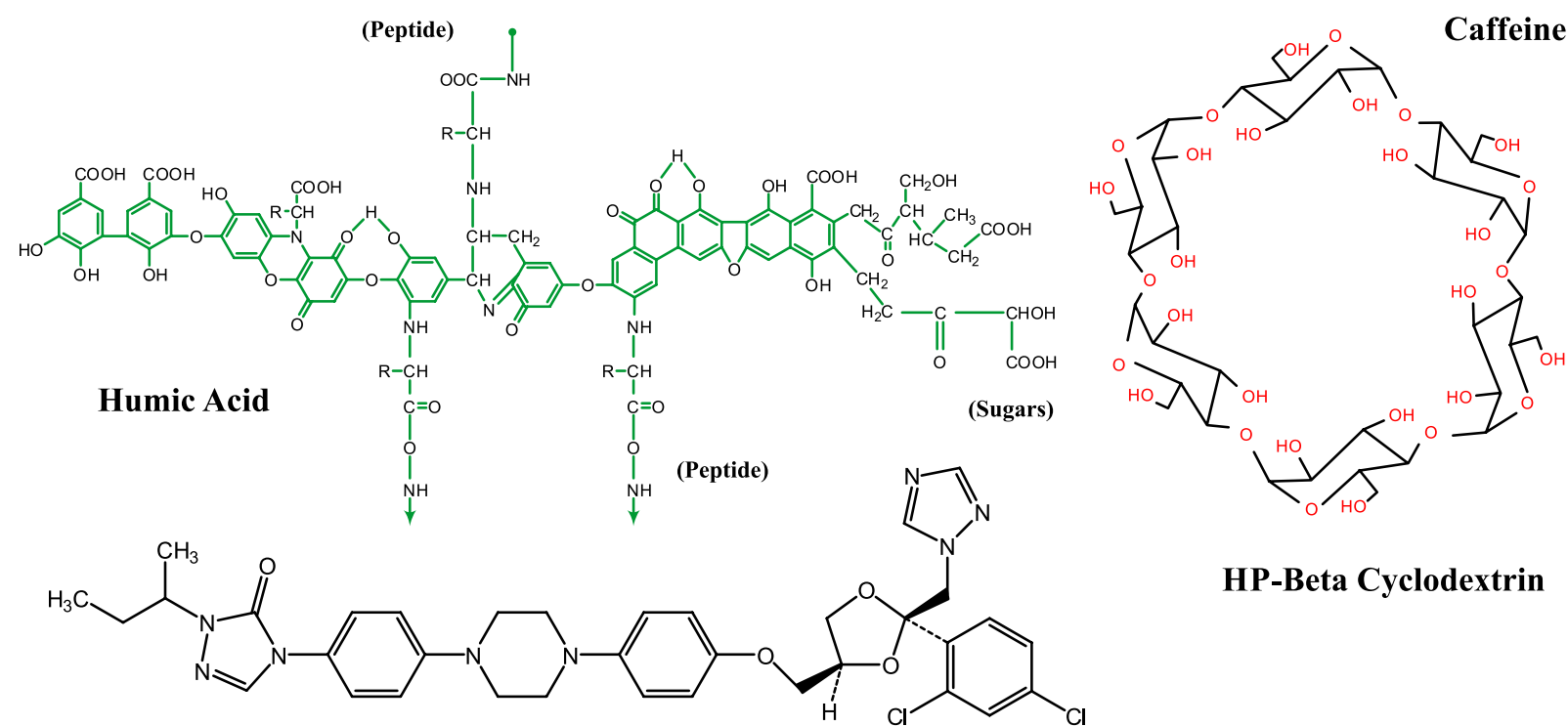

Itraconazole

FIGURE 1- Molecular structure of itraconazole and different complexing agents ( $\beta$ - cyclodextrin, HP- $\beta$-cyclodextrin, caffeine, fulvic acid and humic acid) 
(HP- $\beta$-CD) and caffeine (Caff). Newly introduced humic acid and fulvic acid belong to natural organic matters, which form inclusion complexes with therapeutic molecules (Mirza et al., 2011). Cyclodextrins are torus-shaped oligosaccharides obtained from the enzymatic degradation of starch by bacteria (Szetjli, 1998) which readily form inclusion complexes with many lipophilic organic molecules both in solution and in the solid-state. Caffeine is a natural xanthine alkaloid compound that acts as a central nervous system stimulant and reportedly forms complexes by a charge transfer mechanism (Fouad et al., 2010). The study was aimed at identifying the best drug inclusion complex to be used in treatment of vaginal candidiasis.

\section{MATERIAL AND METHODS}

\section{Material}

Rock shilajit was obtained and authenticated from Dabur Research Foundation, Ghaziabad, India. Itraconazole was obtained as a gift sample from Jubilant Organosys, Noida, India. Chemicals and reagents used for the study were of analytical reagent grade and purchased from Merck India Ltd, Mumbai. Sporanox ${ }^{\circledR}$ (Johnson and Johnson) was purchased from local market. A slightly modified method (Mirza et al., 2010) was used to extract FA and HA from rock shilajit.

\section{Methods}

\section{Equilibrium phase solubility studies}

Phase solubility studies were carried out at room temperature $\left(25^{\circ} \mathrm{C}\right)$ in triplicate according to the method reported by Higuchi and Connors (Vlachou, Papaioannou, 2003). Excess amount of drug was added to distilled water containing various concentrations $(0.2-2 \% \mathrm{w} / \mathrm{v})$ of different complexing agents in a series of stoppered conical flask $(100 \mathrm{~mL})$ and shaken for $48 \mathrm{~h}$ on a mechanical shaker. The suspensions were filtered through 0.45 $\mu \mathrm{m}$ filter paper. The solubility and chemical stability of the drug was also assessed by a slight modification of a validated HPLC method (Yoo et al., 2000), with an accuracy of $95.5 \%$ and a precision of $6.7 \%$. The analysis was carried out on a Waters Alliance e2695 separating module (Waters Co., MA, USA) using photo diode array detector (Waters 2998) with auto sampler and column oven. The instrument was controlled by use of Empower software installed with the equipment for data collection and acquisition. Compounds were separated using a $\mathrm{C} 18$ reverse phase column ( $25 \times 4.6 \mathrm{~mm}$, particle size $5 \mu \mathrm{m}$, Merck, Germany) maintained at room temperature. The mobile phase consisted of acetonitrile, $0.05 \%$ diethylamine in deionized water $(7: 3, \mathrm{v} / \mathrm{v})$, with the $\mathrm{pH}$ adjusted to 7.0 by drop wise addition of phosphoric acid. The flow rate was $1 \mathrm{~mL} / \mathrm{min}$ and the detection wavelength was set at $260 \mathrm{~nm}$. $10 \mu \mathrm{L}$ of the sample was injected into the column. $\mathrm{R}_{\mathrm{t}}$ of Itz was observed at $8.25 \mathrm{~min}$.

\section{Preparation of complexes by Freeze drying method}

The required stoichiometric $(1: 1,1: 2$ and $1: 3)$ quantity of drug was added to an aqueous solution of the complexing agent and was agitated on a magnetic stirrer for $24 \mathrm{~h}$. Sucrose solution $(2 \%, \mathrm{w} / \mathrm{v})$ was added as a cryoprotectant. The resulting solutions were frozen at $\left(-70^{\circ} \mathrm{C}\right)$ in a deep freezer for overnight. This was then lyophilized (Dry Winner, DW-8-85 Heto Holten, Denmark) to obtain a dried mass which was further powdered in a glass mortar and pestle and passed through a 100-mesh sieve to obtain a uniform-size fine powder. The samples were then transferred into vacuum desiccators and dried over silica gel under vacuum for at least $24 \mathrm{~h}$. A similar batch of complex, without cryoprotectant was also developed to carry out instrumental analysis like DSC and XRD.

\section{Characterization of complexes}

- Differential scanning calorimetry

DSC thermograms were obtained under a nitrogen gas flow of $50 \mathrm{ml} / \mathrm{min}$. Calibration of the DSC instrument (DSC-7, Perkin Elmer Pyris 6 instrument, USA) was carried out using indium as standard. Sample powders (5 mg) were crimped in an aluminum pan and heated at a rate of $10 \mathrm{~K}$. $\mathrm{min}^{-1}$. Generally, scan rates were taken between 1 and $10 \mathrm{~K} . \mathrm{min}^{-1}$. Low scan rates are preferable in terms of peak resolution and investigation of the sample having close peaks while high scan rates increase the sensitivity of the measurement as they lead to the exchange of heat within a comparatively short time period. Further, scan rate may also influence the course of temperature related processes within the sample. Samples were heated from 30 to $350{ }^{\circ} \mathrm{C}$ (highest melting points of organic substances).

- $\quad \mathrm{X}$ ray diffraction

XRD samples were studied using X-ray diffractometer (PW 1830, Phillips, Banglore, Karnataka, India). The samples $(1000 \mathrm{mg})$ on XRD plates were rotated during data collection to reduce orientation effects of particles. XRD patterns of all the samples were recorded between $2 \theta=5^{\circ}$ and $70^{\circ}$ at $35 \mathrm{kV}$ and $30 \mathrm{~mA}$, respectively.

- $\quad$ Proton nuclear magnetic resonance ( ${ }^{1} \mathrm{H}$ NMR)

Proton Magnetic Resonance $\left({ }^{1} \mathrm{H}\right.$ NMR) spectra were recorded on Brucker Model DRX-300 NMR spectrometer in $\mathrm{CDCl}_{3}$ using tetramethylsilane (TMS) as the internal standard. Chemical shifts are reported in parts per million 
(ppm, $\delta$ ) and signals are described as singlet (s), doublet $(\mathrm{d})$, triplet (t), quartet (q) and multiplet (m).

- Mass spectroscopy

Mass spectroscopy was carried out only for Itz- FA complexes. Samples were taken from the linear regions of phase solubility study to evaluate the complexation. The samples were dissolved in Milli-Q water to make a stock solution of $1 \mathrm{mg} / \mathrm{mL}$ and then further dilution was prepared in Milli-Q water: Methanol (50:50). Finally a concentration of $100 \mathrm{ng} / \mathrm{mL}$ was prepared and injected into the mass spectrometer (Synapt Mass Spectrometry, Q-TOF with UPLC) on electrospray ionization with positive mode. Capillary, sampling cone, and extraction voltages were $2.51,21$ and 5.3 units respectively. Source and desolvation temperatures were $80^{\circ} \mathrm{C}$ and $250^{\circ} \mathrm{C}$, respectively. Nitrogen gas was used as cone and desolvation gas at 50 and $600 \mathrm{~L} / \mathrm{h}$ respectively, while trap collision energy of 6.0 units was used. The system was from Waters bearing serial No. JAA 272, USA. Software used was MassLynx V 4.1.

- Determination of complexation efficiency

The ability of complexing agents to complex Itz was determined quantitatively by UV spectrophotometer (Hassan et al., 2007). Acetonitrile was used for the determination of free Itz content since complexing agents taken, had poor solubility in acetonitrile and the inclusion complex was also expected to have low solubility in acetonitrile. To estimate free Itz content, $10 \mathrm{mg}$ of the sample was dissolved in $100 \mathrm{ml}$ of acetonitrile. This solution was then sonicated for $2 \mathrm{~min}$, filtered on a $0.45 \mu \mathrm{m}$ filter (Millipore) and analyzed using UV spectroscopy (UV 1601, Shimadzu, Japan) at $260 \mathrm{~nm}$. The free Itz content was determined in triplicate. Following equation was used to determine the complexation efficiency,

$\%$ Inclusion efficiency $=\frac{\text { Total Itz content }- \text { Free Itz content } \mathrm{x} 100}{\text { Total Itz content }}$

\section{Saturation solubility of complexes at vaginal $\mathrm{pH}$}

Excess amount of different complexes were added to $10 \mathrm{ml}$ of an aqueous solution (pH 4.5). They were shaken in a water bath (Ray Scientifics Instruments, India) for 5 days at $37^{\circ} \mathrm{C}$, centrifuged (Tomy MX-305, Japan) at 3000 rpm for $10 \mathrm{~min}$ and filtered using $0.45 \mu \mathrm{m}$ filter paper. The concentration of Itz in the resulting solutions was then analyzed by the method described in earlier section. The resulting values were the average of at least three replicates.

The standard solution Gibbs energies were calculated using following equation:

$$
\Delta \mathrm{G}^{\mathrm{o}}{ }_{\mathrm{sol}}=-\mathrm{RT} \ln \mathrm{X}_{2}
$$

where; $\mathrm{X}_{2}$ is the molar fraction of Itz in a saturated solution.

The standard solution enthalpies $\left(\Delta \mathrm{H}^{\circ}\right)$ were derived from temperature dependencies of drug solubilities expressed in molar fractions (van't Hoff equation):

$$
\mathrm{D} \ln \mathrm{X}_{2} / \mathrm{dT}=\Delta \mathrm{H}^{\circ} \mathrm{sol} / \mathrm{RT}^{2}
$$

For use of the above equation following assumptions were made: (a) the activity coefficients of dissolved drugs do not deviate from unity and (b) the solution enthalpies do not depend on concentration. The solution heat capacities are considered to be constant within studied temperature range, since the temperature dependence of solubility is described by linear equations.

\section{Determination of driving force of solubilisation}

To determine the driving force for solubilisation of the bulk drug and complexes among different thermodynamic parameters (Gibb's free energy, entropy and enthalpy), the following study was carried out. Different aqueous solutions with variable $\mathrm{pH}$ (1 and 4) were prepared by the dropwise addition of conc. $\mathrm{HCl}$ into $100 \mathrm{ml}$ of Milli Q water and the required $\mathrm{pH}$ was confirmed using a pH meter (Decibel 1011, Chandigarh, India). Excess of each sample was added to different $\mathrm{pH}$ solutions and the solubility was determined by the method described in earlier section. Here aqueous solutions of variable $\mathrm{pH}$ were selected instead of buffer solution as in an earlier study (Perlovich et al., 2003) composition of buffer was found to have pronounced effect in determining the thermodynamic driving force for solubility enhancement during the complexation studies.

\section{In vitro release study}

Drug release study of active pharmaceutical ingredient (100 mg Itz suspension) and inclusion complexes (equivalent to $100 \mathrm{mg}$ Itz) was performed using USP II dissolution apparatus (Hanson Research SRS, Chatsworth, CA, USA) in $900 \mathrm{ml}$ of simulated vaginal fluid (Owen, 1995 ) containing $1 \%$ sodium lauryl sulphate at $50 \mathrm{rpm}$ and $37^{\circ} \mathrm{C} \pm 0.5^{\circ} \mathrm{C}$. The study was carried out by transferring the constituted suspension $(5 \mathrm{~mL})$ in dialysis bag (Spectra-Por dialysis bag (Sigma Aldrich, St. Louis, MO, USA) with cutoff 12,000-14,000 Da). The concentration of Itz was determined using HPLC method described earlier. All dissolution studies were carried out in triplicate. 


\section{In vitro antifungal studies}

In vitro antifungal studies were performed against clinical isolates of Candida albicans in Sabouraud's agar medium by the cup plate method. The marketed formulation (Sporanox $100 \mathrm{mg}$ Capsule) was suspended in $2 \mathrm{~mL}$ of sterilized water and transferred into the well of agar plate. Suspension of complexes equivalent to $100 \mathrm{mg}$ of Itz was also prepared in the same manner. $2 \mathrm{ml}$ of distilled water was used as the control. All the samples were applied in triplicate. Covered petridishes were incubated at $32{ }^{\circ} \mathrm{C}$ in the BOD incubator (LHC-78-Labhospmake, India) for 40 $\mathrm{h}$. The zone of inhibition was measured at the end of $40 \mathrm{~h}$.

\section{In vivo antifungal studies}

The in vivo studies in a rat infection model were carried out in order to assess the efficacy of different complexes (De Bernardis et al., 1997). The animal study protocol was duly approved by the Institutional Animal Ethical Committee of Jamia Hamdard (proposal number 742). Twenty four female wistar rats were divided in groups of four for the application of Itz-Caff, Itz-FA, Itz- HP- $\beta$-C D complexes while one group was taken as a control. All the complexes were formulated as $2 \% \mathrm{w} / \mathrm{w}$ thermosensitive gels to ensure an easy application onto the vaginal tissue. An earlier study had reportedly (Francois, 2003) used $5 \mathrm{~g}$ of $2 \%$ Itz cream which was well tolerated and not absorbed systemically and hence it is expected that $2 \% \mathrm{w} / \mathrm{w}$ Itz would not be absorbed systemically in the experimental rat model. Gel was prepared according to the cold method (Choi et al., 1998). Briefly, mucoadhesive polymer (Carbopol 934) $(0.2 \% \mathrm{w} / \mathrm{v})$ was slowly added to citrate phosphate buffer $(0.1 \mathrm{M}, \mathrm{pH} 4.0)$ at $4^{\circ} \mathrm{C}$ with gentle mixing for an hour and allowed to hydrate. Then it was centrifuged at $3000 \mathrm{rpm}$ for $15 \mathrm{~min}$ to remove the air bubbles. Care was taken to allow the minimum air bubbles level during handling. Pluronic ${ }^{\circledR}$ F $127(18 \% \mathrm{w} / \mathrm{v})$ was then added to CP 934 solution and allowed to dissolve overnight at $4{ }^{\circ} \mathrm{C}$. Calculated amount of complexes were then added in a solution form and total volume was adjusted. Six days prior to the inoculation of infection, all animals were maintained under pseudoestrus stage by subcutaneous administration of estradiol benzoate. Into these oophorectomized rats $C$. albicans $\left(10^{8}\right.$ cells per $\mathrm{ml}$ of saline) were inoculated. Then different gels laden with different drug-inclusion complexes $(1 \mathrm{~g})$ were applied. Control constituted of plain placebo gel. During specified time intervals $1 \mu \mathrm{L}$ of the fluid from vaginal cavity was withdrawn, diluted and spread on Sabouraud agar containing chloramphenicol $(50 \mathrm{mg} / \mathrm{mL})$. It was then incubated at $32^{\circ} \mathrm{C}$ in the BOD incubator (LHC-78-Labhospmake, India) for $48 \mathrm{~h}$ and CFUs were counted. A rat was considered infected when at least $1 \mathrm{CFU}$ was present in the vaginal sample (i.e., a count of $\geq 10^{3} \mathrm{CFU} / \mathrm{mL}$ ). A graph was plotted between time (days) and number of CFUs present in vaginal fluid and different complexes studied comparatively.

\section{In vitro cell toxicity studies}

An MTT assay was used to assess the cytotoxicity of the free drug as well as the control and the complexes. The MTT (3-(4,5-dimethylthiazolyl-2)-2,5-diphenyltetrazolium bromide) assay is based on conversion of yellow water soluble tetrazolium dye to a water-insoluble purple formazan by living cells. The amount of formazan generated is directly proportional to the number of viable cells.

MCF-7 cells (ATCC, USA grown in NII, New Delhi) were grown $\left(37^{\circ} \mathrm{C}, 5 \% \mathrm{CO}_{2}\right.$ in water jacketed incubator shell) using DMEM media (Dulbeccos modified agar medium for cell culture growth, Gibco Invitrogen, USA) with $10 \%$ FBS and seeded on a single 96 well plate (Corning costar, USA) and allowed to adhere for MTT assays. Following this a concentration of free drug as well as the control and complexes ranging from $50 \mu \mathrm{g} / \mathrm{mL}$ to 500 $\mu \mathrm{g} / \mathrm{mL}$ having equivalent concentration were added in duplicates to the single 96 well tissue culture plate (Falcon Plate, Corning costar, USA). After 24 hours of treatment, the MTT assay was performed to check cell viability (Mosmann, 1983). For the MTT assay, the media was removed from all the wells, $10 \mu \mathrm{L}$ of MTT reagent (Chemicon International, USA) per well from a working stock $(5 \mathrm{mg} /$ $\mathrm{mL})$ was added and the plates incubated $\left(37^{\circ} \mathrm{C}\right.$ and $5 \%$ $\mathrm{CO}_{2}$ ) for 2-3 $\mathrm{h}$, after that the reagent was removed and the crystals were solubilised using isopropyl alcohol (IPA). This IPA extract (Isopropanol with $0.1 \mathrm{~N} \mathrm{HCl}$ ) was then transferred to 96 well-plates. The $\mathrm{HCl}$ converts the phenol red in the tissue culture medium to a yellow colour that does not interfere with the MTT formazan measurement. The Isopropanol dissolves the formazan to give a homogeneous blue solution. The absorbance was measured at a test wavelength of $570 \mathrm{~nm}$ and reference wavelength of $630 \mathrm{~nm}$ using an ELISA plate reader, LMR-340 M (Labexim International, Austria). The value of absorbance is considered to be the measure of the number of live cells.

\section{RESULTS AND DISCUSSION}

\section{Phase solubility studies}

Phase solubility analyses of Itz in presence of different complexing agents are given in Figure 2. Here different natures of interactions between complexing 
agents and Itz have been observed. Broadly, two types of interactions were observed. In one category curve fitting line was inclined towards Y-axis while in other category, it was inclined towards $\mathrm{X}$-axis. This tendency may be used to predict the comparative orders of complexation. With respect to complexing agents, HA and FA were exhibiting lower order of complexation as compared to HP- $\beta-C D$, $\mathrm{CD}$ and Caffeine. The total solubility $\left(S_{\text {Total }}\right)$ of a drug as a function of concentration of different complexing agents is given by any of the following equations which also give an estimate to predict the stoichiometric ratios of complexation. For single order complexation, solubility relationship is expressed by:

$$
\mathrm{S}_{\text {Total }}=\mathrm{S}_{0}+\mathrm{m}\left[\mathrm{D}_{\mathrm{m}} \mathrm{CA}\right]
$$

where, $\mathrm{S}_{0}$ is the drug concentration in the absence of complexing agents and $m$ refers to the stoichiometry of the complexation. Here, one molecule of the drug interacts with one molecule of complexing agents. Thus, solubility of Itz can be assumed linear and proportional with complexing agent when stoichiometry of complexation is 1 . This is the case with HA and FA. For second order complexation (one drug molecule interacts with two molecules of complexing agents), fitting the data to a quadratic model is appropriate. It is expressed by:

$$
S_{\text {Total }}=\mathrm{S}_{0}+\mathrm{K}_{1: 1} \mathrm{~S}_{0}[\mathrm{CA}]+\mathrm{K}_{1: 1} \mathrm{~K}_{1: 2} \mathrm{~S}_{0}[\mathrm{CA}]^{2}
$$

A positive deviation from the linearity for the phase-solubility diagram and deconvolution of the curve is observed with higher order complexes. In third order complexation, one molecule of the drug interacts with three molecules of complexing agents. To account for the concentration of complexing agents in these cubic relationships (Peeters et al., 2002) suggested a non-linear optimization technique based on Nelder-Mead approach. Higher ordered complexation is observed with remaining complexing agents. So, cyclodextrin molecules $(\beta-C D$ and HP- $\beta-C D$ ) are considered to interact in a fashion of second order. On the other hand caffeine molecule follows a third order pattern which is also evident from the literature.

A phase solubility graph is also used to determine the binding constant and other thermodynamic $(\Delta \mathrm{G}, \Delta \mathrm{H}$ and $\Delta S$ ) parameters (Yadav et al., 2009). The binding constant was calculated according to the formula:

$$
K_{S}=\frac{\text { slope }}{S_{0}(1-\text { slope })}
$$

where, $\mathrm{S}_{0}$ is the solubility of Itz without complexing agents.

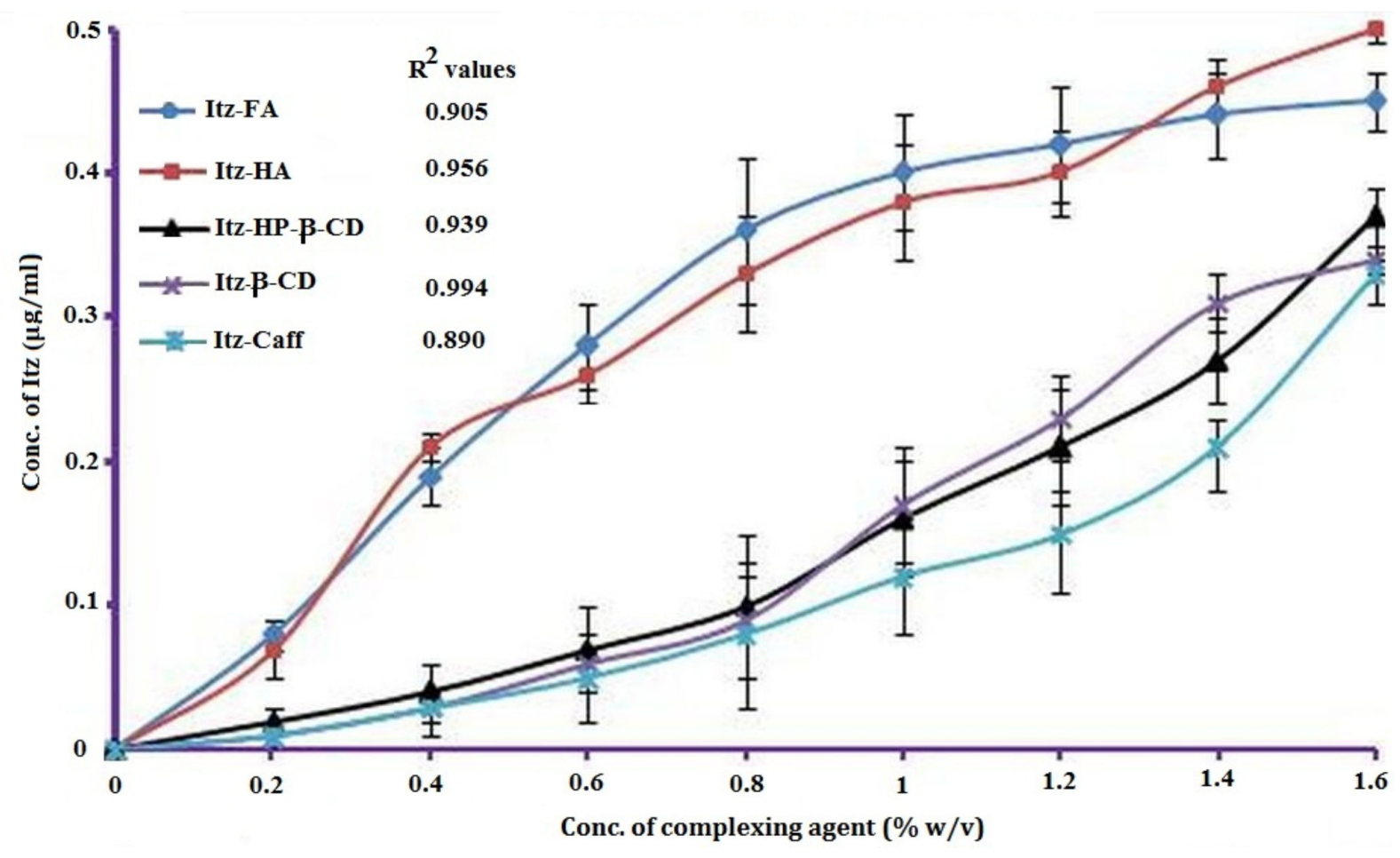

FIGURE 2- Phase solubility studies of Itraconazole at room temperature $\left(25^{\circ} \mathrm{C}\right)$. Curve fitting line appears to be divided into two groups. 
TABLE I - Saturation solubility of complexes at vaginal $\mathrm{pH} 4$

\begin{tabular}{lcccccc}
\hline Substances & $\begin{array}{c}\text { Solubility } \\
(\mu \mathrm{g} / \mathrm{ml}) \text { at } \mathrm{pH} 4\end{array}$ & $\begin{array}{c}X_{2} \\
\text { (molar fraction })\end{array}$ & $\begin{array}{c}\Delta \mathrm{G}^{298}{ }_{\text {sol }} \\
\left(\mathrm{kJ} \mathrm{mol}^{-1}\right)\end{array}$ & $\begin{array}{c}\Delta \mathrm{H}^{298} \text { sol } \\
\left(\mathrm{kJ} \mathrm{mol}^{-1}\right)\end{array}$ & $\begin{array}{c}\mathrm{T} \Delta \mathrm{S}^{298}{ }_{\text {sol }} \\
\left(\mathrm{kJ} \mathrm{mol}^{-1}\right)\end{array}$ & $\begin{array}{c}\Delta S^{298} \text { sol } \\
\left(\mathrm{J} \mathrm{mol}^{-1} \mathrm{~K}^{-1}\right)\end{array}$ \\
\hline 1:1 Itz-FA & $5.81 \pm 1.4$ & $0.149 \times 10^{-6}$ & 38.94 & $48.3 \pm 0.5$ & 9.36 & 31.4 \\
$1: 1$ Itz- HA & $3.11 \pm 0.3$ & $0.08 \times 10^{-6}$ & 40.47 & $52.1 \pm 0.5$ & 11.63 & 39.02 \\
1:2 Itz- HP- $\beta$-CD & $0.221 \pm 0.02$ & $0.005 \times 10^{-6}$ & 47.34 & $47.2 \pm 0.7$ & -0.14 & -0.469 \\
1:2 Itz- $\beta$-CD & $0.179 \pm 0.004$ & $0.0046 \times 10^{-6}$ & 47.55 & $46 \pm 0.9$ & -1.55 & -5.20 \\
1:3 Itz- Caff & $0.156 \pm 0.023$ & $0.00402 \times 10^{-6}$ & 47.88 & $46.1 \pm 1.1$ & -1.78 & -5.97 \\
Itz & $0.13 \pm 3.7$ & $0.0033 \times 10^{-6}$ & 48.46 & $44.5 \pm 0.8$ & -3.96 & -13.28 \\
\hline
\end{tabular}

The binding constant for different complexes was found to be varying like Itz-FA $\left(1104.26 \mathrm{M}^{-1}\right)$, Itz-HA $\left(1024.65 \mathrm{M}^{-1}\right)$, Itz-HP- $\beta$-CD $\left(1012.44 \mathrm{M}^{-1}\right)$, Itz- $\beta$-CD $\left(993.47 \mathrm{M}^{-1}\right)$ and Itz- Caffeine $\left(568.21 \mathrm{M}^{-1}\right)$. Stability constant $\left(\mathrm{K}_{\mathrm{s}}\right)$ values lying between 200 and $5,000 \mathrm{M}^{-1}$ are considered as most suitable for the improvement of solubility and stability of a poorly soluble drug (Patel, Patel; 2007). To investigate the spontaneity and feasibility of the entrapment by the thermodynamic approach, changes in Gibb's free energy $(\Delta G)$ were also calculated (at constant temperature and pressure). It is the net energy available for useful work.

$$
\Delta \mathrm{G}_{\text {sol }}^{\mathrm{o}}=-\mathrm{RT} \ln \mathrm{X}_{2}
$$

Where, $\mathrm{X}_{2}$ is the molar fraction of Itz in a saturated solution. Results obtained are given in Table I. Other thermodynamic parameters are obtained by using Van't Hoff equation. $K_{s}$ are calculated at different temperatures and $\Delta \mathrm{H}$ is calculated according to the equation given below;

$$
\log \mathrm{K}_{2} / \mathrm{K}_{1}=-\frac{\Delta \mathrm{H}}{2.303 \mathrm{R}}\left(\mathrm{T}_{2} / \mathrm{T}_{1}-\mathrm{T}_{1} / \mathrm{T}_{2}\right)
$$

or,

$$
\log \mathrm{K}_{2} / \mathrm{K}_{1}=-\frac{\Delta \mathrm{H}}{2.303 \mathrm{R}}+\text { Const }
$$

Thus, if a plot is drawn between $1 / \mathrm{T}$ and $\log \mathrm{K}$, slope of the plot will be $\Delta \mathrm{H}$. Entropy may be calculated using the equation:

$$
\Delta \mathrm{G}=\Delta \mathrm{H}-\mathrm{T} \Delta \mathrm{S}
$$

\section{Characterization of complexes}

\section{Differential scanning calorimetry}

DSC is a tool to investigate the melting and re-
TABLE II - DSC of pure Itraconazole, complexing agents and complexes

\begin{tabular}{lccc}
\hline Samples & $\Delta \mathrm{H}(\mathrm{j} / \mathrm{g})$ & $\begin{array}{c}\text { Maximum } \\
\text { peak }\left({ }^{\circ} \mathrm{C}\right)\end{array}$ & Peak width \\
\hline Itz & 105.035 & 170.408 & 6.62 \\
FA & 142.075 & 162.387 & 11.13 \\
Itz-FA & 78.502 & 136.214 & 26.44 \\
HA & 44.236 & 77.365 & 44.63 \\
Itz-HA & 31.461 & 163.628 & 16.50 \\
HP- $\beta-C D$ & 33.768 & 119.876 & 31.42 \\
Itz- HP- $\beta-C D$ & 69.119 & 161.452 & 11.22 \\
$\beta-C D$ & 117.96 & 127.625 & 41.26 \\
Itz- $\beta$-CD & 49.825 & 147.473 & 8.32 \\
Caffeine & 124.630 & 198.524 & 7.46 \\
Itz- Caff & 69.215 & 81.213 & 4.29 \\
\hline
\end{tabular}

crystallization behavior of crystalline materials. Organic substances usually show a melting range. An increased melting range could be correlated with impurities or less ordered crystals. The DSC analysis showed a sharp peak of Itz at $170^{\circ} \mathrm{C}$. None of the complexing agents showed any sharp peak except Caffeine at $192^{\circ} \mathrm{C}$. All the complexes exhibited broad humps at variable temperature ranges (Figure 3). It may be inferred from the thermograms that Itz may have lost its crystalline pattern and thus is present in its amorphous form. The details from the thermograms of Itz and its complexes are given in Table II.

Melting enthalpy $(\Delta \mathrm{H})$, expressed in joule/gram $(\mathrm{J} / \mathrm{g})$ is a characteristic of the crystal order if the influence of impurities can be ignored. For the less ordered crystal or amorphous state, the melting of the substance requires less energy than the perfect crystalline substance which is required to overcome the lattice energy. As a result, the higher melting enthalpy values should suggest higher ordered lattice arrangement and vice versa. The higher enthalpies were noted with single entities 


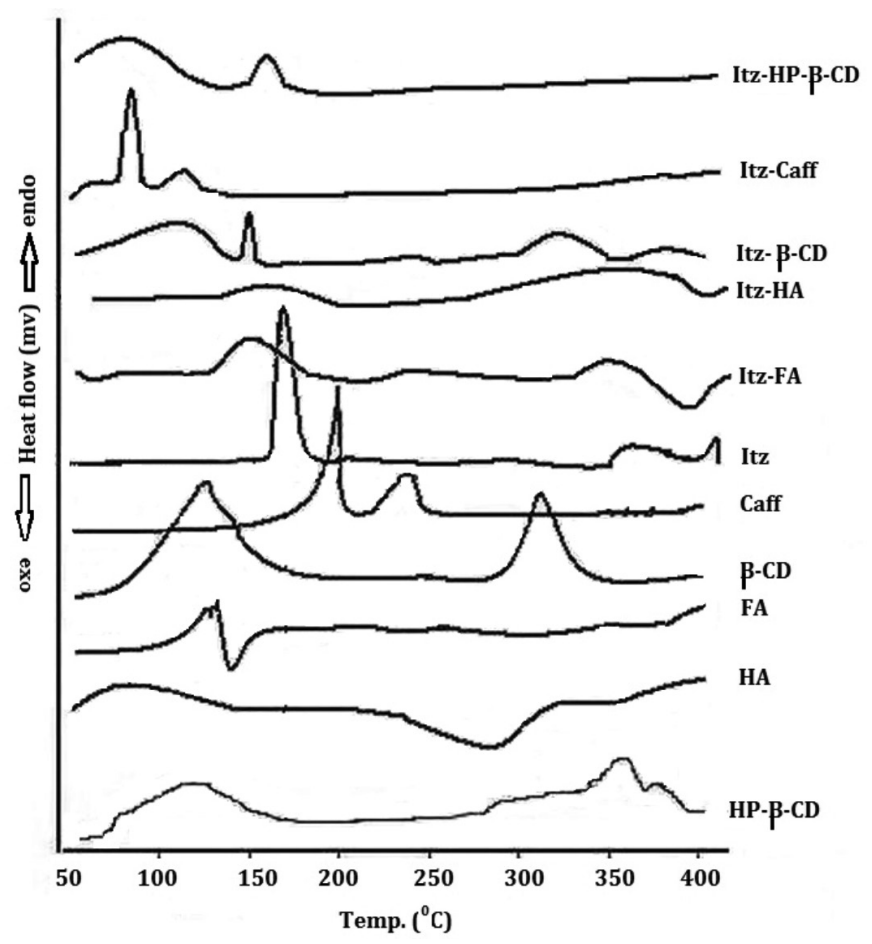

FIGURE 3- Representative DSC profiles of itraconazole, complexing agents and different complexes.

like Itz (105.035 j/g), FA (142.075 j/g), $\beta$-CD (117.96 $\mathrm{j} / \mathrm{g})$ and caffeine $(124.630 \mathrm{j} / \mathrm{g})$. So far the complexes are concerned, $\Delta \mathrm{H}$ values were comparatively lower. Thus, it may be inferred from the results that complexes have more disordered structures. This decrease in disorder is created due to positive interaction between two entities (drug and complexing agents).

Peak width is another parameter to study but it depends largely upon particle size especially in nanometric range as explained by Gibbs-Thomson equation:

$$
\operatorname{Ln} \mathrm{T} / \mathrm{T}_{0}=2 \gamma_{\mathrm{sl}} \mathrm{V}_{\mathrm{s}} / \mathrm{r} \Delta \mathrm{H}_{\text {fus }}
$$

where, $\mathrm{T}$ - Melting temperature of a particle with radius $\mathrm{r}$; $\mathrm{T}_{0}$ - Melting temperature of the bulk material at the same external pressure; $\gamma_{\mathrm{sl}}$ - Interfacial tension at the solid-liquid interface; $\mathrm{V}_{\mathrm{S}}-$ Specific volume of the solid; $\Delta \mathrm{H}_{\text {fus }}-$ Specific heat of fusion

Peak width is actually an integration of peaks of different size ranges. When the particle size distribution is wide spread, it is higher and vice versa. The particle size of unprocessed drug is around $152.3 \mathrm{~nm}$ with a PDI of 0.8 . Other samples were passed through sieve 100 hence a higher size distribution could be expected.

Although DSC is able to monitor and quantify even minute thermal events in the sample (depending on the sensitivity of the instrument) and to identify the tempera- tures at which these events occur. But it does not directly reveal the cause of a thermal event. The exact nature of the thermal transitions has to be determined with other complementary methods such as microscopic observations, X-ray diffraction or spectroscopic techniques to distinguish, for example, between melting, polymorphic transitions, loss of water from hydrates or decomposition of the substance.

\section{$X$-ray diffraction}

Use of these two techniques (DSC and XRD) often lead to complementary information on the systems of interest and data evaluation from these methods is usually straight forward. Such a plot (2 $\theta V S \%$ Intensity) can be considered a fingerprint of the crystal structure and to differentiate with different crystallographic status of the system. One peak will be exhibited for all repeating planes with the same spacing. By contrast, an amorphous sample will exhibit a broad hump in the pattern called an amorphous halo. These patterns are representative of the structure but do not give positional information about the atoms in the molecule. Itz was showing a characteristic crystalline pattern (Figure 4) exhibiting intense peaks at $20.38(100 \%), 20.40(97.59 \%), 20.36$ (96.53\%), 20.34 (88.53\%), 20.32 (80.66\%) and 17.5 $(77.9 \%)$ etc. Few sharp peaks were present only in caffeine $(100 \%$ at $11.24,49.56 \%$ at 27.32 , and $47.64 \%$ at $28.42)$ and HP- $\beta-C D(100 \%$ at $12.34,39.40 \%$ at 23.68 , $42.52 \%$ at $25.34 \mathrm{etc}$ ). Other complexing agents (FA, HA and $\beta-C D$ ) were almost amorphous in nature (Figure 5). $\mathrm{XRD}$ of Itz-HA and Itz-FA showed amorphous nature and some diminished peaks were observed in Itz-HP- $\beta$ $\mathrm{CD}$, Itz- $\beta-\mathrm{CD}$ and Itz- Caffeine complexes (Figure 4). These peaks were not from the fingerprint regions of Itz but from the complexing agents themselves. Thus, the XRD of inclusion complexes showed their amorphous nature, indicating entrapment of drug and, peaks if any were appreciably diminished.

\section{Proton nuclear magnetic resonance ( $\left.{ }^{1} \mathrm{HNMR}\right)$}

The ${ }^{1} \mathrm{H}$ NMR spectra of Itz (Figure 6) showed singlet protons at $\delta 8.29$ and 8.37 for triazoles nucleus. While ${ }^{1} \mathrm{H}$ NMR spectra of Itz- $\beta$-CD complex showed two singlet peaks at $\delta 8.31$ and 8.39 which are slighlty downfield shifted peaks. All the other peaks of both $\beta-C D$ and Itz remain almost unchanged. This clearly indicates the inclusion phenomena of the triazoles nucleus into the $\beta$-CD cavity (Spulber et al., 2008). Nearly same phenomena was observed for inclusion complex of Itz with FA, HA and HP- $\beta$-CD. The downfield shift values observed were $\delta 8.32$ and 8.44 for Itz-FA, $\delta 8.34$ and 8.42 


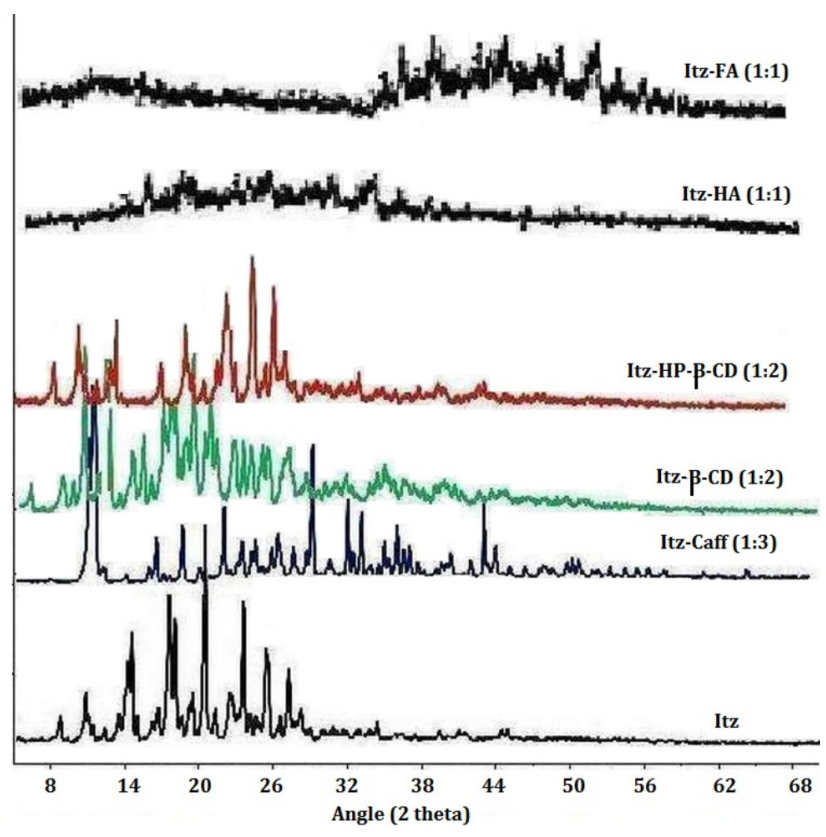

FIGURE 4- X-ray powder diffraction of itraconazole and complexes.

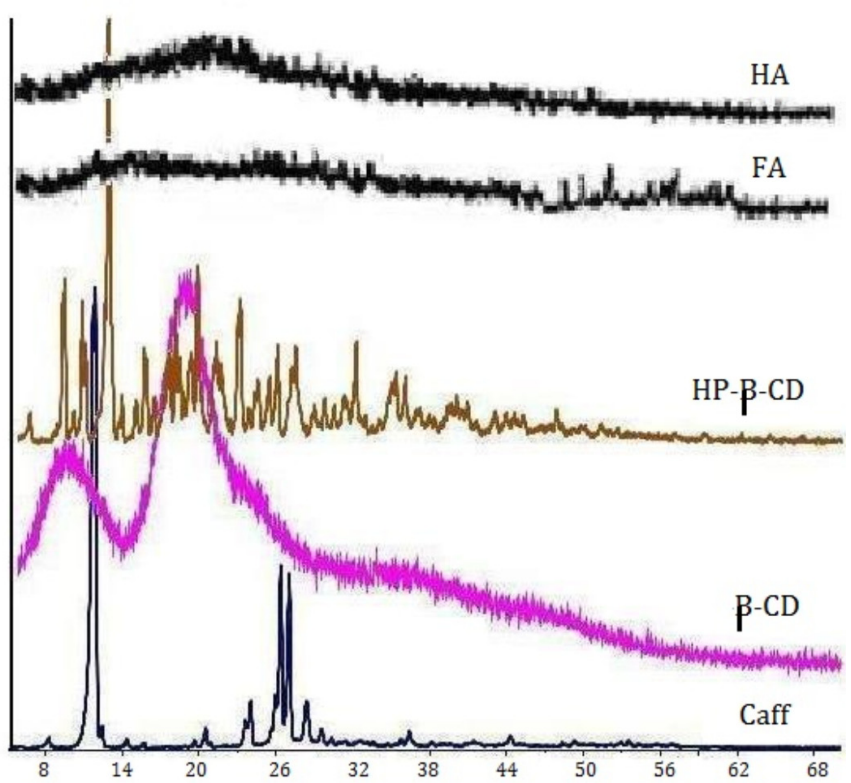

FIGURE 5- X-ray powder diffraction of complexing agents.

for Itz-HA, $\delta 8.30$ and 8.40 for Itz- HP- $\beta$-CD. ${ }^{1} \mathrm{H}$ NMR spectra of Itz-caffeine complex also showed changes in both the protons and shifting pattern of the proton in Itz-and caffeine. $\mathrm{H}_{8}$ proton of caffeine was observed at $\delta 7.90$ where as Itz-caffeine complex showed $\mathrm{H}_{8}$ peak as upfolded doublet at $\delta 7.84$. Also triazole nucleus of Itz showed one singlet at $\delta 8.28$ and doublet at $\delta 8.34$. This clearly indicates the introduction of $\mathrm{H}_{8}$ (caffeine) with $\mathrm{H}_{3}$ of triazole.

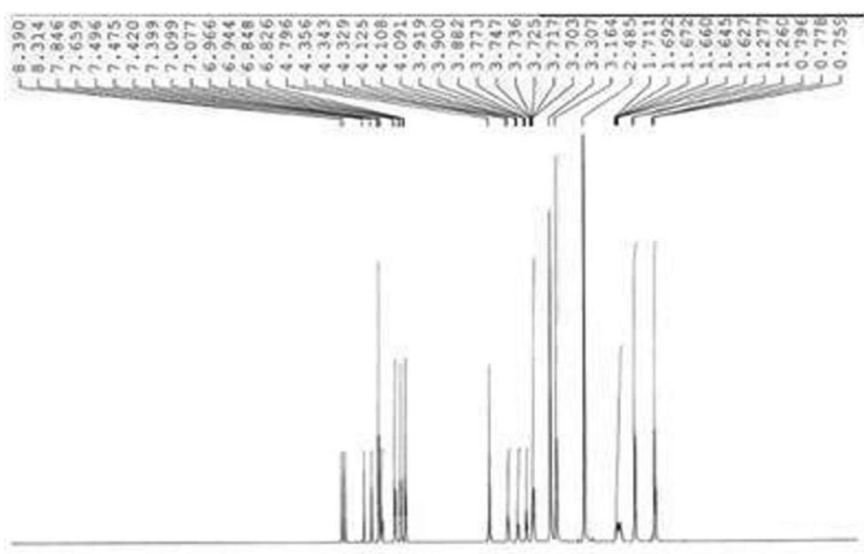

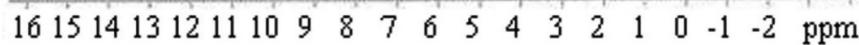

FIGURE 6- NMR spectra of itraconazole.

\section{Mass spectroscopy}

The various studies had elicited that fulvic acid was a better complexing agent hence; mass study was carried only for this. A representative spectrum is given in Figure 7. In all the mass spectra some peaks were common (with $\mathrm{m} / \mathrm{z}$ variation $\sim 5$ ) that were either non-complexed drug (Itz), non-complexed fulvic acid (avg. molecular wt $1200)$ or $1: 1$ and 1:2 complexes. Extensive noise was also present. It was evident from the result that in any complex (irrespective of the ratio) some fraction of uncomplexed drug, uncomplexed fulvic acid and 1:2/ 1:1 complexes were present. Their relative abundances depended upon the ratio $(1: 1$ or $1: 2)$ taken.

\section{Determination of complexation efficiency}

The results obtained for complexation efficiency studies are given in Table III. All the complexes showed appropriate acceptability except Itz-Caffeine complex ( 47.54). In author's point of view this may not be a very appropriate method to determine the complexation efficiency as high sonication energy may result into dissociation of no bond complexes (inclusion complex). However, due to unavailability of any appropriate method, authors had to follow the reported method.

TABLE III - Complexation efficiencies of different complexes

\begin{tabular}{lc}
\hline Samples & \% Complexation efficiency $\pm \mathrm{SD}(\mathrm{n}=3)$ \\
\hline $1: 1$ FA-Itz & $67.32 \pm 2.6$ \\
$1: 1$ HA-Itz & $59.21 \pm 1.9$ \\
$1: 2$ Itz- HP- $\beta$-CD & $61.48 \pm 3.3$ \\
$1: 2$ Itz- $\beta$-CD & $58.31 \pm 1.4$ \\
$1: 3$ Itz- Caff & $47.54 \pm 2.7$ \\
\hline
\end{tabular}




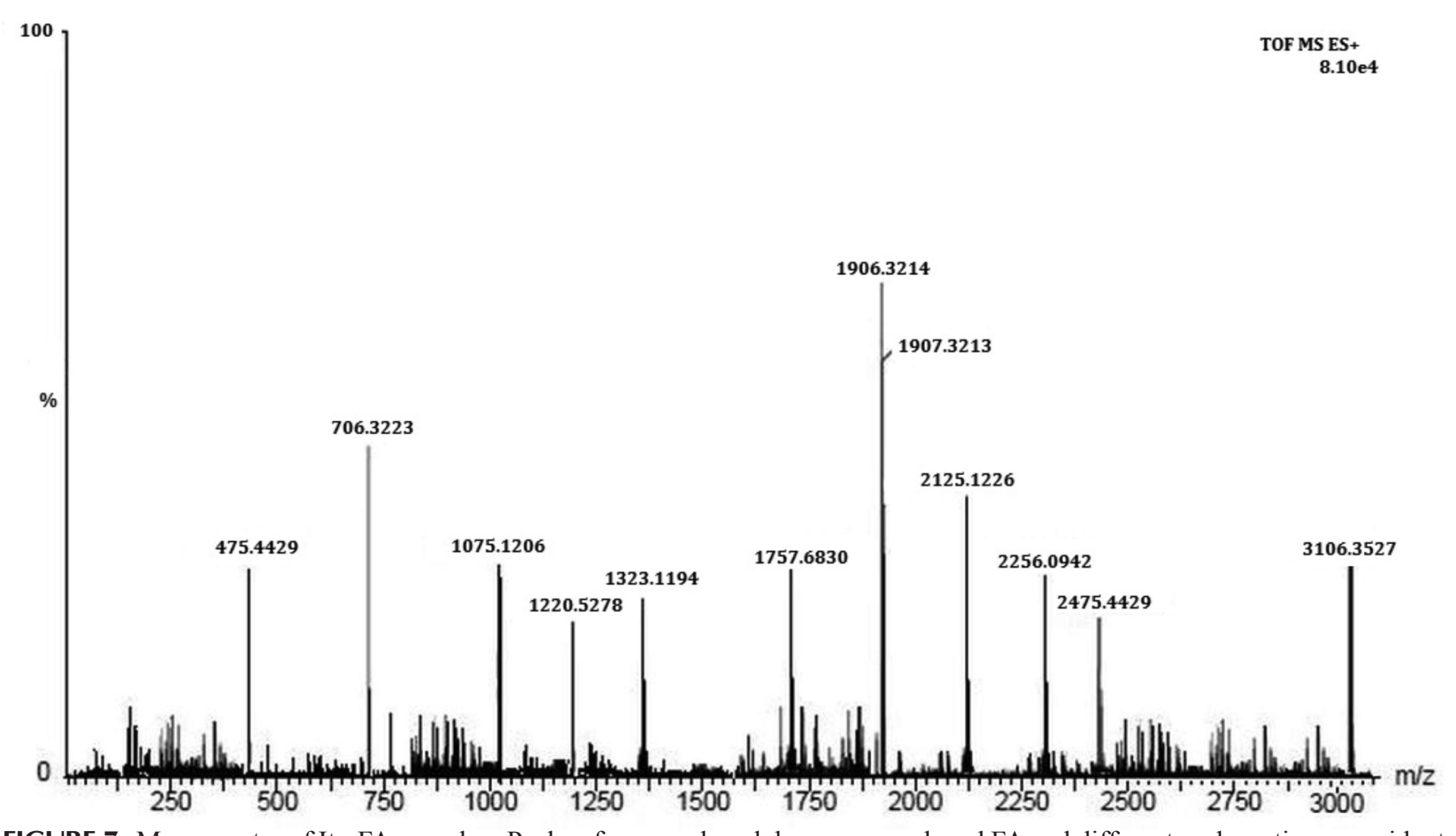

FIGURE 7- Mass spectra of Itz-FA complex. Peaks of uncomplexed drug, uncomplexed FA and different molar ratios are evident in the spectra obtained.

\section{Saturation solubility of complexes at vaginal $\mathrm{pH}$}

The study was conducted for over a period of five days which yielded saturated samples. The maximum solubility was observed with 1:1 Itz-FA complex (5.81 \pm 1.4 $\mu \mathrm{g} / \mathrm{mL}$ ). Decreasing order of solubility is given in Table I. Thermodynamic parameters $(\Delta \mathrm{G}, \Delta \mathrm{H}$ and $\Delta \mathrm{S})$ calculated for the samples are also given in the same table. Positive signs of enthalpy of solublisation $(\Delta \mathrm{H})$ indicate that it is an endothermic process at room temperature and crystal lattice energy of the substance outweighs the solvation energy. Positive values of $\Delta G$ also indicate that the process is non-spontaneous at room temperature and is driven by some energy source. Nature of change of disorder $(\Delta S)$ is different in all systems (complexes). In case of HA and FA complexes, it is increasing (positive values) while in other cases (HP- $\beta-C D, \beta-C D$ and Caffeine) it is decreasing (negative values). With increasing disorder of the system, we may expect better encapsulation of one moiety into another.

\section{Determination of driving force of solubilization}

Thermodynamic parameters calculated for different samples presented a clear picture about the driving forces involved when the $\mathrm{pH}$ is varied in acidic range (4 to 1 ). Vaginal milieu is acidic at normal physiological conditions but often rises to alkaline during infections. Marketed for- mulations like Aci-gel, Buffer gels etc are often prescribed to maintain vaginal acidity which eventually curtails the vaginal floral growth. Conclusively, there is a significant $\mathrm{pH}$ variation in the vaginal cavity. Itz also elicits variation in ionic state at different $\mathrm{pH}$ which translates into differential interaction with the complexing agents. Itz is a weak base with four ionizable nitrogen atoms. The two $\mathrm{pKa}$ values are 4 and 1.5-2 whereas the other ionizable nitrogen is not protonated between $\mathrm{pH} 2$ and 10 (Peeters et al., 2002). Also the $\mathrm{p} K_{\mathrm{a}}$ of the nitrogen atom of the triazolone moiety is 4.0 . This explains the sudden drop in solubility above $\mathrm{pH} 3$ and the associated changes in both solubility and dissolution. It also explains non linear (ascending or descending) pattern for any thermodynamic parameter during complexation. The sudden drop in solubility of Itz above $\mathrm{pH} 3$ leads to a greater hydrophobic interaction of guest and host molecules and the Itz penetrates deep into the host molecule thus creating Van der Waals interaction and hydrogen bonds thereafter. For the complexes and API the values of $\Delta \mathrm{G}$ and $\Delta \mathrm{H}$ are positive ( $\Delta \mathrm{S}$ were found to be both positive and negative). Thus we can conclude that complexation of Itz with fulvic acid is non-spontaneous at low temperature while spontaneous at high temperature. Here, terms low temperature and high temperatures are relative terms. For a particular reaction, high temperature could mean room temperature also. 
TABLE IV - Thermodynamic parameters of solubilisation process of pure Itraconazole, 1:1 FA-Itz and 1:1 HA-Itz, 1:2 Itz- HP- $\beta$ $\mathrm{CD}, 1: 2$ Itz- $\beta$-CD and 1:3 Itz-Caff complexes in aqueous solution at variable $\mathrm{pH}$ at $298 \mathrm{~K}$

\begin{tabular}{lcccccccc}
\hline Samples & $\mathrm{pH}$ & $\begin{array}{c}\text { Solubility } \\
(\mu \mathrm{g} / \mathrm{ml})\end{array}$ & $\begin{array}{c}X_{2} \text { (molar } \\
\text { fraction) }\end{array}$ & $\begin{array}{c}\Delta \mathrm{G}^{298}{ }_{\text {sol }} \\
\left(\mathrm{kJ} \mathrm{mol}^{-1}\right)\end{array}$ & $\begin{array}{c}\Delta \mathrm{H}^{298} \\
\left(\mathrm{~kJ} \mathrm{~mol}^{-1}\right)\end{array}$ & $\begin{array}{c}\mathrm{T} . \Delta \mathrm{S}^{298}{ }^{\text {sol }} \\
\left(\mathrm{kJ} \mathrm{mol}^{-1}\right)\end{array}$ & $\begin{array}{c}\Delta S^{298}{ }^{\text {sol }} \\
\left(\mathrm{J} \mathrm{mol}^{-1} \mathrm{~K}^{-1}\right)\end{array}$ & $\varepsilon \mathrm{S}^{\mathrm{a}}[\%]$ \\
\hline API (Itz) & 1 & $24.17 \pm 2.3$ & $0.618 \times 10^{-6}$ & 35.42 & $55.3 \pm 0.71$ & 19.88 & 66.71 & 56.12 \\
& 4 & $0.13 \pm 3.7$ & $0.0033 \times 10^{-6}$ & 48.46 & $44.5 \pm 0.8$ & -3.96 & -13.28 & -8.17 \\
1:1 FA-Itz & 1 & $78.46 \pm 2.6$ & $2.02 \times 10^{-6}$ & 32.48 & $38.3 \pm 0.6$ & 5.82 & 19.5 & 17.91 \\
& 4 & $5.81 \pm 1.4$ & $0.149 \times 10^{-6}$ & 38.94 & $48.3 \pm 0.5$ & 9.4 & 31.4 & 24.13 \\
1:1 HA-Itz & 1 & $33.26 \pm 1.3$ & $0.857 \times 10^{-6}$ & 34.60 & $58.1 \pm 1.8$ & 23.5 & 78.85 & 67.91 \\
& 4 & $3.11 \pm 0.3$ & $0.08 \times 10^{-6}$ & 40.47 & $52.1 \pm 0.5$ & 11.63 & 39.02 & 28.73 \\
1:2 Itz- HP- $\beta$-CD & 1 & $92.56 \pm 1.7$ & $2.38 \times 10^{-6}$ & 32.07 & $42.3 \pm 0.7$ & 10.23 & 34.32 & 31.89 \\
& 4 & $0.221 \pm 0.02$ & $0.005 \times 10^{-6}$ & 47.34 & $47.2 \pm 0.7$ & -0.14 & -0.47 & -0.29 \\
1:2 Itz- $\beta-C D$ & 1 & $83.17 \pm 3.2$ & $2.14 \times 10^{-6}$ & 32.33 & $40.6 \pm 0.4$ & 8.27 & 27.75 & 25.57 \\
& 4 & $0.179 \pm 0.004$ & $0.0046 \times 10^{-6}$ & 47.55 & $46 \pm 0.9$ & -1.55 & -5.2 & -3.25 \\
1:3 Itz- Caff & 1 & $56.48 \pm 2.4$ & $1.46 \times 10^{-6}$ & 33.28 & $48.5 \pm 0.8$ & 15.22 & 51.07 & 45.77 \\
& 4 & $0.156 \pm 0.023$ & $0.00402 \times 10^{-6}$ & 47.88 & $46.1 \pm 1.1$ & -1.78 & -5.97 & -3.71 \\
\hline
\end{tabular}

${ }^{a} \varepsilon S=\left[\left(T . \Delta S^{\circ}\right) / \Delta G^{\circ}\right] \cdot 100$

Change in entropy (as the $\mathrm{pH}$ of the solution was moved from 4 to 1 ) was observed to be the main driving force as it increased substantially. Although it was negative also in case of 1:1 Itz-FA, but other factors $(\Delta \mathrm{G}$ and $\Delta \mathrm{H})$ were more negative as compared to $\Delta \mathrm{S}$ (Table IV). At $\mathrm{pH}$ 1, Itz molecule has a solvation shell, which consists of entropically ordered molecules of the medium in the space next to the ionized atoms, and a more disordered part of the solvation shell is located around other parts of the molecule (hydrophobic effect). Thus during complexation the ordered shell portion along with some other hydrophobic portions finds its way into the cavity leaving behind disordered portions.

\section{In vitro release studies}

The results obtained after dissolution study are given in Figure 8. To analyze the in vitro release data various kinetic models were used to describe the release kinetics. The zero order rates describe the systems where the drug release rate is independent of its concentration. The first order describes the release from system where release rate is concentration dependent (order is one). Higuchi described the release of drugs from insoluble matrix as a square root of time dependent process based on Fickian diffusion. Whereas, Peppas Korsemeyer describes the log fraction of drug release with respect to log time. Release order of all the complexes appears to be first order (Table V). To evaluate the mechanism of drug release from the preparation, data of drug release may be plotted in Korsmeyer and Peppas equation (Korsmeyer et al., 1983):

$$
\log \left(M_{\mathrm{t}} / M_{f}\right)=\log \mathrm{K}+\mathrm{n} \log \mathrm{t}
$$

It is often used to describe the drug release behavior from polymeric systems. Where $\mathrm{M}_{\mathrm{t}}$ is the amount of drug release at time $t, M_{f}$ is the amount of drug release after infinite time; $\mathrm{k}$ is release rate constant incorporating structural and geometric characteristics of the dosage form, $n$

TABLE V - Release kinetics and mechanism involved with different complexes

\begin{tabular}{lcccccc}
\hline \multirow{2}{*}{ Formulations } & Zero-order & First-order & Higuchi matrix & \multicolumn{2}{c}{ Korsmeyer-peppas } & \multirow{2}{*}{ Best fit model } \\
\cline { 2 - 5 } & $r^{2}$ & $r^{2}$ & $r^{2}$ & $r^{2}$ & Rel. Expo. $(n)$ & \\
\hline 1:1 Itz-FA & 0.967 & 0.995 & 0.974 & 0.960 & 0.326 & First order \\
1:1 Itz- HA & 0.967 & 0.982 & 0.932 & 0.960 & 0.319 & First order \\
1:2 Itz- HP- $\beta-C D$ & 0.967 & 0.988 & 0.963 & 0.960 & 0.326 & First order \\
1:2 Itz- $\beta$-CD & 0.967 & 0.968 & 0.946 & 0.960 & 0.326 & First order \\
1:3 Itz- Caff & 0.967 & 0.996 & 0.990 & 0.960 & 0.326 & First order \\
\hline
\end{tabular}


is the diffusional exponent indicative of the mechanism of drug release. The log value of percent drug dissolved is plotted against log time for each formulation according to the equation. For a cylinder shaped matrix the value of $\mathrm{n} \leq 0.45$ indicates Fickian release; $>0.45$ but $<0.89$ for non-Fickian (anomalous) release; and $>0.89$ indicates super diffusion type of release. It generally refers to the erosion of the polymeric chain and anomalous transport (Non-Fickian) refers to a combination of both diffusion and erosion controlled drug release. In all five complexes release appears to be Fickian diffusion $(n \leq 0.326)$.

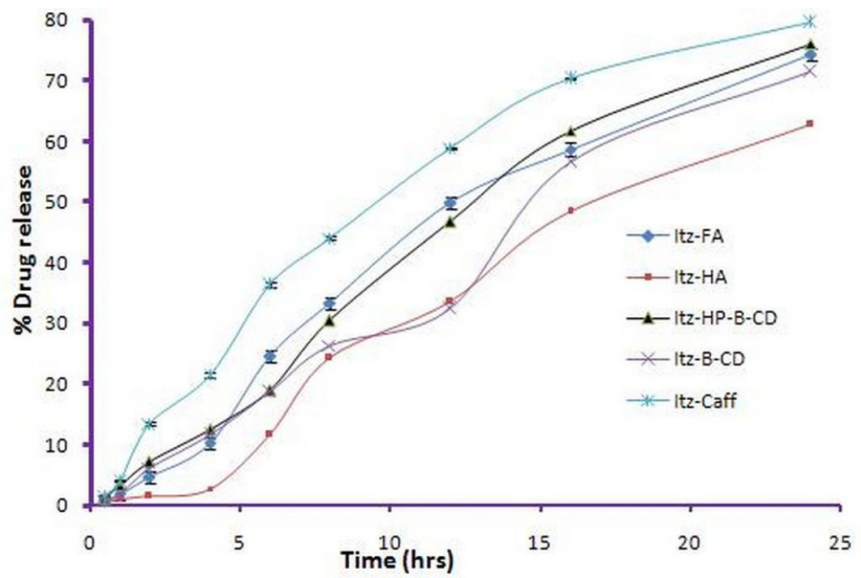

FIGURE 8 - In vitro drug release profile of complexes. Maximum drug release was observed with Itz-Caff complexes. While minimum was observed with Itz-HA complexes. Thus later appears to have a more sustained release profile.

\section{In Vitro antifungal studies}

All the wells except those containing control (distilled water) produced an appreciably larger zone of inhibition than Itz alone. Smallest zone produced by pure Itz may be due to minimal solubility of the drug in an aqueous media. Sporanax and 1:2 Itz-HP- $\beta$-CD produced almost similar zones as the same excipient is used in both. Among all complexes 1:3 Itz-Caff produced smallest zone. It is quite evident from earlier data that caffeine complexes were showing minimal solubility. Since, the size of zone largely depends upon the solubility and diffusibility of the sample through the agar media hence the results are inferred with this perspective (Table VI).

\section{In vivo antifungal studies}

Three complexes (Itz-Caff, Itz-FA and Itz-HP- $\beta$-CD) whose performances were better in release studies and in vitro antifungal studies were submitted for in vivo infection model studies (Figure 9). Control was not having any drug but little improvement in infection was observed which may be due to conditioning effect of carbopol 934. Highest ame-
TABLE VI - In vitro anti fungal activity of different complexes by cup-plate method

\begin{tabular}{lc}
\hline Substances & Zone of inhibition $(\mathrm{n}=3)$ in $\mathrm{cm}$ \\
\hline Distilled water & -- \\
Sporanax $100 \mathrm{mg}$ Capsule & $1.6 \pm 0.3$ \\
$100 \mathrm{mg} \mathrm{Itz}$ & $0.4 \pm 0.2$ \\
$1: 1$ Itz-FA & $1.5 \pm 0.4$ \\
$1: 1$ Itz-HA & $1.1 \pm 0.2$ \\
$1: 2$ Itz- HP- $\beta-C D$ & $1.7 \pm 0.2$ \\
$1: 2$ Itz- $\beta-C D$ & $1.4 \pm 0.3$ \\
$1: 3$ Itz- Caff & $0.9 \pm 0.2$ \\
\hline
\end{tabular}

lioration was effected by Itz-FA. But unexpectedly, Itz-Caff performed better than Itz-HP- $\beta-C D$ which was not evident in vitro antifungal studies. As per the authors' inferences, it may be due to two factors favoring caffeine complexes. Although similar solubility profile was obtained in case of both the complexes but a non-concentration gradient mechanism of drug release is involved in case of caffeine. Moreover, caffeine and Itz are bound together by charge transfer mechanism and this complex may de-stabilize quickly resulting into a faster drug release, better dissolution and a noticeable therapeutic effect. This behavior is well supported by the acidic and ionic nature of vaginal milieu which adds to a higher dielectric constant of the medium.

On the other hand an HP- $\beta$-CD- Itz complex releases drug by a sheer mechanism which only involves diffusion based on the concentration gradient.

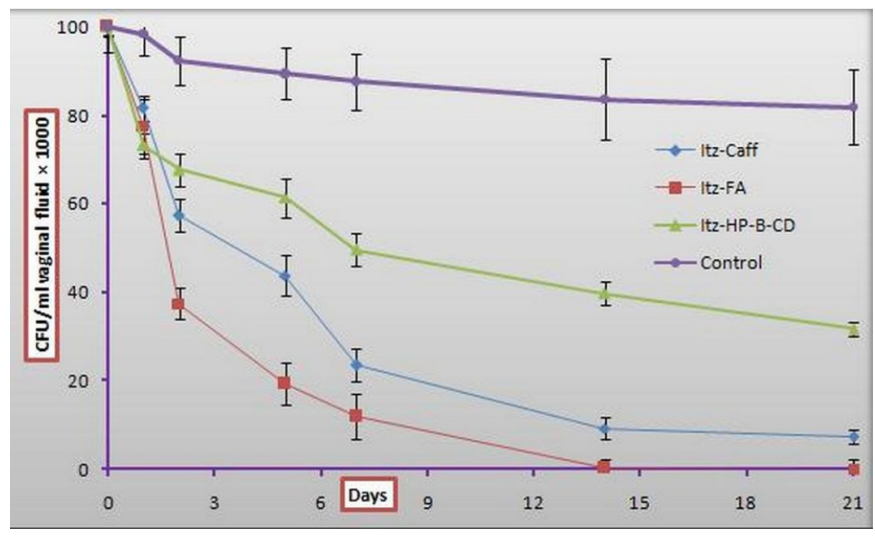

FIGURE 9- Outcome of vaginal infection by C. albicans in oophorectomized, estradiol-treated rats after infections with $10^{8}$ C. albicans cells. Each curve represents the mean (6 standard error) of the fungal CFU of six rats.

\section{In vitro cell toxicity studies of complexes}

The corresponding values for optical density for the control, neat drug and the complexes are shown in 
Figure 10. Itz as a pure drug was found to have some cytotoxic effect. At the lowest concentration $(50 \mu \mathrm{g} / \mathrm{mL})$ relative difference of cell death was not distinguishable from each other, although none of them interfered with cell growth. However at higher concentrations $(100 \mu \mathrm{g} / \mathrm{mL}, 200 \mu \mathrm{g} / \mathrm{mL}$ and $500 \mu \mathrm{g} / \mathrm{mL}$ ) some conclusive results were obtained. HP$\beta-\mathrm{CD}$ and $\beta$-CD complexes showed some negative pattern in cell growth as compared to other complexing agents. However, for the complexes the toxicity did not increase at higher concentrations. Thus, the reports of in vitro cell toxicity study did not indicate any serious cellular toxicity and the results are in agreement with earlier studies which reported humic substances to be safe according to the cytotoxicity studies (Yamada et al., 2007).

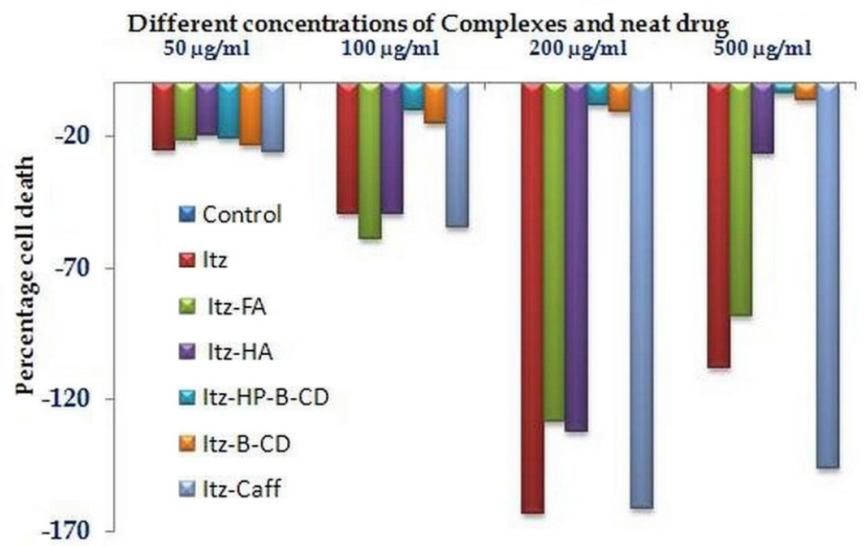

FIGURE 10 - MTT assay results of pure drug and complexes. At lower concentrations all constituents were showing similar effect on cell growth. But the differences were evident at higher concentrations.

\section{CONCLUSION}

Itz-inclusion complexes have been successfully used to improve the performance of this poorly soluble drug. Fulvic acid, a naturally occurring substance, has displayed its suitability as a complexing agent which can successfully harness the potential of Itz as an antifungal agent. Its topical application in the form of a gel can be effectively used to ameliorate vaginal candidiasis, which is a recurrent problem in women of reproductive age. In an earlier communication we have shown the evaluation of a tablet constituting of Itz-FA. Fortunately, fulvic acid had elicited an adequate acid buffering and mucoadhesion properties, which strongly supports its use in the physiologically variable $\mathrm{pH}$ milieu of the vaginal cavity. Conclusively, an Itz-FA inclusion complex offers a promise for development of a purported formulation for treatment of vaginal candidiasis.

\section{ACKNOWLEDGEMENT}

Authors are grateful to Mr. Zaheen Hasan (Dept. of Pharmaceutical chemistry, Jamia Hamdard) for interpretation of different spectra. Authors are also thankful to Dr. Syed Shahabuddin (Dept. of Physics, University of Delhi) for his help in X-ray diffraction studies. For the help in different mathematical calculations, authors are thankful to Er. Asad Eqbal, Er. Afshan Tarannum, Er. Tabish kafeel, Niyaz Ahmed and Er. Javed Alam.

\section{REFERENCES}

BAILEY, E.M.; KRAKOVSKY, D.J.; RYBAK, M.J. The triazole antifungal agents: a review of itraconazole and fluconazole. Pharmacotherapy, v.10, p.146-153, 1990.

CHOI, H.G.; JUNG, J.H.; RYU, J.M.; YOON, S.J.; OH, Y.K.; KIM, C.K. Development of in situ gelling and mucoadhesive acetaminophen liquid suppository. Int. J. Pharm., v.165, 33-44, 1998.

COMO, J.A.; DISMUKES, W.E. Oral azole drugs as systemic antifungal therapy. N. Eng. J. Med., v.330, p.263-272, 1994.

DE BERNARDIS, F.; BOCCANERA, M.; ADRIANI, D.; SPREGHINI, E.; SANTONI, G.; CASSONE, A. Protective role of antimannan and anti-aspartyl proteinase antibodies in an experimental model of Candida albicans vaginitis in rats. Infect. Immun., v.65, p.3399-3405, 1997.

FOUAD, E.A.; El-BADRY, M.; ALANAZI, F.K.; ARAFAH, M.M.; Al-ASHBAN, R.; ALSARRA, I.A. Preparation and investigation of acetyl salicylic acid-caffeine complex for rectal administration. Pharm. Dev. Tech., v.15, p.249-257, 2010.

FRANCOIS, M.; SNOECKX, E.; PUTTEMAN, P.; WOUTERS, F.; DE PROOST, E.; DELAET, U.; PEETERS, J.; BREWSTER, M.E. A Mucoadhesive, Cyclodextrin-based Vaginal Cream Formulation of Itraconazole. AAPS Pharm. Sci., v.5, p.50-54, 2003.

GRANT, S.M.; CLISSOLD, S.P. Itraconazole: a review of its pharmacodynamic and pharmacokinetic properties, and therapeutic use in superficial and systemic mycoses. Drugs, v.37, p.310-344, 1989. 
HASSAN, H.A.; AL-MARZOUQI, A.H.; JOBE, B.; HAMZA, A.A.; RAMADAN, G.A. Enhancement of dissolution amount and in vivo bioavailability of itraconazole by complexation with $\beta$-cyclodextrin using supercritical carbon dioxide. J. Pharm. Biomed. Anal., v.45, p.243-250, 2007.

KIPP, J.E. The role of solid nanoparticle technology in the parenteral delivery of poorly water-soluble drugs. Int. J. Pharm., v.284, p.109-122, 2004.

KORSMEYER, R.W.; GURNY, R.; DOELKER, E.; BURI, P.; PEPPAS, N.A. Mechanisms of solute release from porous hydrophilic polymers. Int. J. Pharm., v.15, p.25-35, 1983.

MAERTENS, J.A. History of the development of azole derivatives. Clin. Microbiol. Infect., v.10, p.1-10, 2004.

MIRZA, M.A.; AGARWAL, S.P.; RAHMAN, M.A.; RAUF, A.; AHMAD, N.; ALAM, A.; IQBAL, Z. Role of humic acid on oral drug delivery of an antiepileptic drug. Drug Dev. Ind. Pharm., v.37, p.310-319, 2011.

MOSMANN, T. Rapid colorimetric assay for cellular growth and survival: application to proliferation and cytotoxicity assays. J. Immunol. Methods, v.65, p.55-63, 1983.

OWEN, D.H.; KATZ, D.F. A vaginal fluid stimulant. Contraception, v.59, p.91-95, 1999.

PATEL, R.P.; PATEL, M.M. Preparation and evaluation of inclusion complex of lipid lowering drug lovastatin with ß-cyclodextrin. Dhaka. Univ. J. Pharm. Sci., v.6, p.25-36, 2007.

PEETERS, J.; NEESKENS, P.; TOLLENAERE, J.P.; VAN REMOORTERE, P.; BREWSTER, M.E. Characterization of the interaction of 2-hydroxypropyl- $\beta$-cyclodextrin with itraconazole at pH 2, 4 and 7. J. Pharm. Sci., v.91, p.414422, 2002.
PERLOVICH, G.L.; SKAR, M.; BAUER-BRANDL. Driving forces and the influence of the buffer composition on the complexation reaction between ibuprofen and HP- $\beta-C D$. Eur. J. Pharm. Sci., v.20, p.197-200, 2003.

PRENTIS, R.A.; LIS, Y.; WALKER, S.R. Pharmaceutical innovation by the seven U.K.-owned pharmaceutical companies. Brit. J. Clin. Pharmacol., v.25, p.387-396, 1998.

SPULBER, M.; PINTEALA, M.; FIFERE, A.; HARABAGIU, V.; SIMIONESCU, B.C. Inclusion complexes of 5 -flucytosine with $\beta$-cyclodextrin and hydroxypropyl- $\beta$ cyclodextrin: characterization in aqueous solution and in solid state. J. Incl. Phenom. Macrocycl. Chem., v.62, p.135-142, 2008.

SZETJLI, J. Introduction and general overview of cyclodextrin chemistry. Chem. Rev., v.98, p.1743-1753, 1998.

VLACHOU, M.; PAPAiOANNOU, G. Preparation and characterization of the inclusion complex of furosemide with hydroxypropyl-beta-cyclodextrin. J. Biomater. Appl., v.17, p.197-206, 2003.

YADAV, V.R.; SURESH, S.; DEVI, K.; YADAV, S. Effect of cyclodextrin complexation of curcumin on its solubility and antiangiogenic and anti-inflammatory activity in rat colitis model. AAPS. Pharm. Sci. Tech., v.10, p.752-762, 2009.

YAMADA, P.; ISODA, H.; HAN, J.K.; TALORETE, T.P.; ABE, Y. Inhibitory effect of fulvic acid extracted from Canadian sphagnum peat on chemical mediator release by RBL2H3 and KU812 cells. Biosci. Biotechnol. Biochem., v.71, p.1294-1305, 2007.

YOO, S.D.; KANG, E.H.; JUN, H.; SHIN, B.S.; LEE, K.C.; LEE, K.H. Absorption, First- pass metabolism, and disposition of itraconazole in rats. Chem. Pharm. Bull, v.48, p.798-801, 2000.

Received for publication on $23^{\text {rd }}$ February 2012 Accepted for publication on $15^{\text {th }}$ October 2012 